\title{
Dynamics of Culture Shock on Nomadic Students at Faculty of Social Sciences Makassar State University (Anthropological Perspective)
}

\author{
Andi Ima Kesuma* \\ Department of education Anthropology \\ Faculty of Social Science \\ Universitas Negeri Makassar \\ Makassar, Indonesia \\ andi.ima.kesuma@unm.ac.id
}

\begin{abstract}
This research aimed to 1) Identify and analyze the phenomena of culture shock on nomadic students, especially at the Faculty of Social Sciences Makassar State University; 2) Finding the pattern of the students who migrated at Makassar State University to adapt and how the adaptation process is carried out by following the four stages in culture shock theory; 3 ) introducing the results of this research to all elements ranging from students as a research subject, lecturers, and society. In general, to be more open and more sensitive to the phenomena that exist. The research was a qualitative approach with the phenomenological method. The purpose of using this phenomenological method was to find the visible meaning of the phenomenon of culture shock and the process of adaptation carried out by nomadic students, especially at the Faculty of Social Sciences Makassar State University. The data collection methods were including structured interviews, observations, documentation, and literature review. The results showed that 1) there were a variety of diverse phenomena on nomadic students at UNM both from the area of origin and the time of residence in Makassar; 2) In general, nomadic students in the process are able to adjust to the new environment. But in some cases, they still maintain the usual patterns in accordance with their respective regions.
\end{abstract}

Keywords: Culture Shock, Students, Overseas

\section{INTRODUCTION}

Symptoms of culture shock in Nomadic students occur in almost all campuses in Indonesia. for example, In Makassar, which is a symbol of the city of Education in eastern Indonesia, many students and nomadic students who generally come from several regions such as East Nusa Tenggara, West Nusa Tenggara, and other areas in the minority will feel the culture shock even though in a form that is vary depending on previous experience and knowledge.

Research of nomadic students in Yogyakarta that culture shock occurs in several things, such as 1) pattern, type, taste, and eating portion; 2) Language; 3) custom; 4) gesture / facial expression; 4) Education; 5) association; 6) geographical; and 7) religion [1]. Correspondingly,
Dayakisni explained that culture shock can occur in different environments regarding individuals who experience migration from one region to another within their own country (intra-national) and individuals who moves to another country for a long period of time [2].

Some forms of a culture shock to the students above also occurred at Makassar State University, especially in the Faculty of Social Science. As for some things that will be the main focus of this research on nomadic students who study at the Faculty of Social Science of UNM include 1) association, this relates to how new student looks and gets along well with students from the same area, how they get along with nomadic students from other regions, and most importantly how they get along with students from South Sulawesi in particular; 2) views on culture. There is a tendency to primordialism in people who come from different regions, whether he considers the local culture is lower or maybe also considered higher. Nevertheless, this culture shock is actually the beginning to arrive at adjustment. It can be noted from what is called Lysgaard [3] in culture shock there is a U-Curve Hypothesis which starts from the optimistic phase, followed by a cultural problem, then recovery/understanding emerges, and finally the adjustment phase, this also applies for nomadic students at UNM.

The occurrence of culture shock does not stand alone, the different character of society at the same time causes this to happen. The character of Bugis community-Makassar, of course, in this case, remains a benchmark for incoming students. Some of these characters such as "Stubborn and quite assertive, respect for parents (there is a culture of siri 'na pace), stubborn, irritable. Because the descendants of the king so that the way to speak and behave is regulated and must know the family lineage and local language, trusting the myths so that the space is limited "[4]. Of course students from other ethnic groups, for example, at least during their wanderings in Makassar must understand the character and adapt, for example when students from Flores with characters who are in some ways like angry, assertive, but they are also independent and helpful. 
This research aims to uncover and analyze how nomadic students at Makassar State University carry out process and activity so that they are able to adapt to their new environment. The findings of this research are can not be used as a reference both theoretical and practical to be able to understand each other both between migrants and as native people in Makassar. Theoretically, the result of this research can be a reference at the same time, because there have not been so many in-depth analyzes of the symptoms of culture shock written by many researchers, therefore, this research is urgent enough to be the basis for understanding these social events.

\section{RESEARCH METHOD}

The research approach was qualitative research, as described by Danzin and Lincoln [5] which is a research approach that uses scientific background research with the intention of interpreting phenomena that occur and is carried out by involving various existing method. The research method was the phenomenological method, in which the human world was not understood as an objective world in terms of physical material, but the world as lived by the subject as a person [6].

The research subjects were students outside the South Sulawesi area at the Faculty of Social Science, Hamzanwadi University. Data collection techniques were obtained through interviews, observation, document research, and documentation. The data validity technique was by extending participation, expert team discussion, and checking the adequacy of reference [7].

\section{RESULT AND DISCUSSION}

\section{General Description}

As one of the well-known universities in the eastern part of Indonesia in addition to several other renowned universities such as UNHAS and others, Makassar State University (UNM) has many students from various regions in Indonesia. Just a little description of this can be identified from the Faculty of Social Science in accordance with the focus of this research shows how students from various regions in Eastern Indonesia in particular and Indonesia, in general, make this campus as their reference. The number of students from outside the area in several study programs for the past 4 (four) years is as follows: 1) Anthropology education of 55 good people from other regions in Sulawesi such as West Sulawesi; they also came from Jakarta, NTT and NTB; 2) Study Program of History Education a total of 29 people from West Sulawesi, Bangka Beliting, Kalimantan, and NTB; 3) Study Program of Sociology Education as many as 48 people from Kalimantan, West Sulawesi, Central Sulawesi, and NTT; 4) 18 PPKn Study Program is from Kalimantan, NTB, and West Sulawesi; 5) Office Study Program of Administration as many as 32 people both from NTB, Java, West Sulawesi, Central Sulawesi, NTT, and Kalimantan; 6) and several other study programs such as the Study Program of State Administration, Study Program of Business Administration, and Study Program of Social have quite a number of students from outside South Sulawesi, whose number is not small.

\section{The Dynamics of Culture Shock of Nomadic} Students Regarding Indigenous Culture.

For Nomadic students who study in Makassar, especially at UNM in general based on the story and what they watch on television with an anarchist demonstration they think there is one character that cannot be separated from the community of South Sulawesi, namely the character who is hard, and quick to anger and firm about something. This character has also been used as a precaution and caution for nomadic students both to act, say when they are in Makassar.

The hard and decisive character mentioned above is basically at the same time balanced with other very good characters that are easy to be friendly, have a high sense of caring, and like to help. This is usually recognized by nomadic students after a little shock with information circulating that students or the communities of South Sulawesi are known to be loud and assertive, but after hanging out for a long time, these hard characters do not seem to be of much concern because they are replaced by other very good views.

The disappointment of nomadic students who initially often occurs, they can simply adjust to at least about one year. And it is recognized that one of the hard characters that are often a consideration for nomadic students is the character of the original student who is quick to anger.

The factor of the urban community's habit is one that is quite difficult for nomadic students to follow. The community' s habit in city is to buy luxury goods and often go out at night is one that is often avoided even though invited to do so. Because most nomadic students have a mediocre economy that is indeed difficult to adjust to the allluxurious city life.

Besides other things, there is one other thing that causes overseas students to be slightly disturbed by their presence in Makassar. This is not related to the character but rather to the environment and geography. A noisy environment with crowds as one of the metropolitan cities in Indonesia and its very hot geographical situation often becomes a challenge for overseas students to try to adjust to long periods of time [8].

\section{The Dynamics of Culture Shock in the Association of nomadic students with Native Students/ Communities}

The Frustation situation for a new student who comes and knows the community / native students is more due to the communication factor, especially when they are both using the native language when communicating with others. 
In this case, there is a good intention, it is not understood will be able to cause offense [9].

The ability to understand the language of Bugis / Makassar, although for nomadic students long-distance, one of them is due to the distance and lack of communication or association between the native community and nomadic students. This is of course due to the dominance of students' activity to be on campus as well as doing a lot of college assignments rather than hanging out directly with the community. This situation has certainly never been an obstacle for the native community and students to get along well. As a comparison, language barriers have actually become part of culture shock for nomadic students in other areas, Mitasari' s research result (2018) at UNITRI show that in the first year there is usually a communication breakdown.

The situation often happens otherwise, when there are genuine students who often invite together to an incoming student, even not a few of them who subtly refused. This means that more nomadic students often keep their distance, this is certainly inseparable from the lifestyle that is thought about.

Culture shock arising from a new meeting with different background between nomadic students and the students / indigenous community above basically does not create a big gap, only limited to the different ways of adjusting to the circumstance and ability from a new student who is sometimes unable to follow the style living community / native student.

The absence of a big difference held by both nomadic students and native students causes a harmonization between them. Especially at the Social science faculty of UNM in recent years, this has caused no conflict between them. Even some of the newcomers admitted that sometimes there were more conflicts between fellow students than there were conflicts with students from other regions or with the native student. The result of research conducted by Kacung Marijan and shows regional identity among students has never been part of the basis of a large conflict[10].

\section{The Dynamics of Culture Shock of Nomadic} Students on the Aspect of Food Needs

Food and beverage are also often one of the obstacles for nomadic students, but in general Indonesian people do not have special constraints in this regard, as well as the nomadic students at UNM, most of them feel as usual or like being in their area, although a small portion among them who like to cook themselves according to taste, for example students from NTB prefer a slightly spicy taste. But in general this food and drink is not an obstacle at all for nomadic students in Makassar, especially at UNM.

Need of Food and beverage are also related to eating patterns, which are mostly not many students from outside the area can follow it, such as eating habits that are a bit expensive and seem luxurious, in this case students from outside the area usually choose cheap food menus or they mix itself as explained before.

Not a few of the nomadic students who are in addition to lecture at the same time want to understand the true culture by trying out all the specialties of Makassar and South Sulawesi in general, so that after they go home they can become material for story or knowledge about South Sulawesi for them.

The price of food and drink is also often one of the complaints for nomadic students who feel the cost of living, especially for eating and drinking, is far more expensive compared to prices in their area [11] [12]. In Lombok or NTB in general for example, although in the City there is still a lot of rice which costs Rp.5,000, while in Makassar it is at least above Rp. 10,000, so that not a few among the newcomer who initially felt a little shock, but over time they kept trying to adjust to their economic condition, for example in a more economical way.

5. The Dynamics of Culture Shock of Nomadic Students in the Aspect of Facility and Infrastructure

Facility and infrastructure to support survival while in Makassar is also not uncommon for nomadic students. Some of the reasons they feel a little depressed by the previous situation include the high cost of living in Makassar, which is very different from when they were in their area.

For basic facilities and infrastructure, lectures are never a problem for new students, because from their respective regions they already understand what they will experience, starting from the cost of boarding houses which is quite expensive, no private vehicles, and other shortcomings at all not affect. This means that in the context of culture shock, the availability and lack of adequate facility and infrastructure due to the lack of nomadic students' ability to have it has never happened.

\section{CONCLUSION}

Makassar State University is one of the favorite universities in Sulawesi which is a destination for students from various regions to study. Most students, especially in FIS as an example, generally come from several other areas in Sulawesi such as Central Sulawesi, West Sulawesi and Southeast Sulawesi. Whereas for other regions there are those from NTT, NTB, Kalimantan and Java. As migrant students, not a few students who initially felt various obstacles both caused by cultural factors and urban lifestyles are indeed very different from life in the village in general, because most students who studied at UNM previously lived in rural areas.

\section{ACKNOWLEDGMENT}

The implementation of this research cannot be separated from the role of various parties ranging from good cooperation with the Anthropology Program of Makassar 
State University, Regional Archives Agency, Culture and Tourism Department, and some colleagues who provide advice and input so that the implementation of this research can be carried out properly.

\section{REFERENCES}

[1] M. Devinta, "Fenomena Culture Shock (Gegar Budaya) Pada Mahasiswa Perantauan Di Yogyakarta (Skripsi)," Jur. Pendidik. Sosiol. Fak. Ilmu Sos. Univ. Negeri Yogyakarta, 2015.

[2] T. Dayakisni and S. Yuniardi, Psikologi lintas budaya. Penerbitan Universitas Muhammadiyah Malang (UMM Press), 2004.

[3] L. S. S. Utami, "Teori-Teori Adaptasi Antar Budaya," J. Komun., vol. 7, no. 2, pp. 180-197, 2016

[4] E. M. P. Dewi, "Gambaran Karakter dan Aspirasi terhadap Pendidikan Karakter pada Mahasiswa Psikologi Universitas Negeri Makassar (Unm)," Inq. J. Ilm. Psikol., vol. 7, no. 2, 2016.

[5] J. Moeloeng, "Lexi. Metode Penelitian Kualitatif Edisi Revisi." Bandung: Rosdakarya, 2007.

[6] I. Gunawan, "Metode penelitian kualitatif," Jakarta Bumi Aksara, vol. 143, 2013.

[7] M. D. Walling, J. L. Duda, and L. Chi, "The perceived motivational climate in sport questionnaire: Construct and predictive validity," $J$. Sport Exerc. Psychol., vol. 15, no. 2, pp. 172-183, 1993.

[8] J. Farrer, International Migrants in China's Global City: The New Shanghailanders. Routledge, 2019.

[9] M. R. Freiermuth and M. F. Ito, "Seeking the source: The effect of personality and previous experiences on university students' L2 willingness to communicate," Learn. Motiv., vol. 71, p. 101640, 2020.

[10] A. R. Zaripova and A. R. Zakirov, "The Separatist Sentiments in Spain: The Role of National and Regional Identities' Conflict," Res. Appl. Linguist., vol. 10, no. Proceedings of the 6th International Conference on Applied Linguistics Issues (ALI 2019) July 19-20, 2019, Saint Petersburg, Russia, pp. 1041-1048, 2019.

[11] Y. Taufik, "Change and continuity on the margins: livelihood transformation in Routa Southeast Sulawesi, Indonesia," 2016.

[12] T. Harford, Fifty things that made the modern economy. Hachette UK, 2017. 